\title{
CEACAM5 wt Allele
}

National Cancer Institute

\section{Source}

National Cancer Institute. CEACAM5 wt Allele. NCI Thesaurus. Code C54407.

Human CEACAM5 wild-type allele is located within 19q13.1-q13.2 and is approximately 21

$\mathrm{kb}$ in length. This allele, which encodes carcinoembryonic antigen-related cell adhesion molecule 5 protein, is involved in the facilitation of hepatic metastasis. The wild-type function is currently unknown, however allelic variants have been implicated in several cancers. 